Konya Mühendislik Bilimleri Dergisi, c. 9, Özel Sayı, 213-223, 2021

Konya Journal of Engineering Sciences, v. 9, Special Issue, 213-223, 2021

ISSN: 2667-8055 (Electronic)

DOI: $10.36306 /$ konjes.998111

\title{
ANALYSIS OF THE EFFECT OF PHYSICAL PROPERTIES OF DRUG CO-CRYSTALS ON DISSOLUTION CONCENTRATION
}

\author{
1,2,3,4Sinem ELMAS ${ }^{(i)}$, 1 Fatma Elif GENCELİ GÜNER \\ ${ }^{1}$ Chemical and Metallurgical Engineering Faculty, Chemical Engineering Department, Istanbul Technical \\ University, 34469, Maslak, Istanbul, TURKEY \\ 2 Faculty of Engineering and Natural Sciences, Sabanci University, Istanbul, TURKEY \\ ${ }^{3}$ Integrated Manufacturing Technologies Research and Application Center, Sabanci University, Istanbul, \\ TURKEY \\ ${ }^{4}$ Composite Technologies Center of Excellence, Sabanci University-Kordsa, Istanbul, TURKEY \\ 1,2,3,4 elmassinem@sabanciuniv.edu, ${ }^{1}$ gencelie@itu.edu.tr
}

(Geliş/Received: 14.10.2021; Kabul/Accepted in Revised Form: 27.12.2021)

\begin{abstract}
Psoriasis is an itchy and non-contagious skin disease. Its treatment method varies according to the severity of the disease. In oral treatments used in heavy stages, dissolution behavior is a vital characterization parameter for evaluating cocrystal, understanding dissolution mechanism, and predicting bioavailability of the drug. In this study, dissolution of cocrystals used in psoriasis was investigated. Effect of (i) different shapes, (ii) sizes, and (iii) grinding of cocrystals on the dissolution were considered with ultraviolet-visible (UV/Vis) spectroscopy. Results show that different physical properties and grinding can significantly increase the dissolution of cocrystals.
\end{abstract}

Keywords: Cocrystal, Dissolution concentration, Grinding, UV/Vis spectroscopy

\section{İlaç Ko-Kristallerinin Fiziksel Özelliklerinin Çözünme Konsantrasyonuna Etkisinin Analizi}

ÖZ: Sedef hastalığı bulaşıcı olmayan bir deri hastalığıdır. Hastalığın tedavi yöntemi şiddetine göre değişmektedir. Şiddetli evrelerde ağız yolu ile yapılan tedavilerde, çözünme davranışı, ko-kristali değerlendirmek, çözünme mekanizmasını anlamak ve ilacın biyoyararlanımını tahmin etmek için önemli bir karakterizasyon aşamasıdır. Bu çalışmada sedef hastalığının ağız yoluyla tedavisinde kullanılan kokristallerin (i) farklı şekil, (ii) boyutlarının ve (iii) öğütme işleminin çözünme davranışı üzerindeki etkisi ultraviyole-görünür (UV/Vis) spektroskopisi ile analiz edilmiştir. Çözünme konsantrasyonunun değişen fiziksel özellikler ve öğütme işlemi ile birlikte arttığı kanıtlanmıştır.

Anahtar Kelimeler: Kokristal, Çözünme konsantrasyonu, Öğütme, UV/Vis spektroskopisi

\section{INTRODUCTION}

Active pharmaceutical ingredient (API) is the term used to refer to the biologically active ingredient of a drug (e.g., tablet, capsule). These components play a direct role in diagnosing, curing, treating, or preventing the disease. Drugs usually consist of several ingredients, in this case, API is the primary ingredient, and other ingredients are often known as an excipient and should always be biologically safe (Chan et al., 2014). Pharmaceutical ingredients can be divided into several categories according to their solid-state form, namely, the formation of salts, amorphous, polymorphs, hydrates, solvates, and cocrystals, as illustrated in Figure 1. Each solid form provides different physicochemical properties such as solubility, bioavailability. (Schultheiss \& Newman, 2009). 


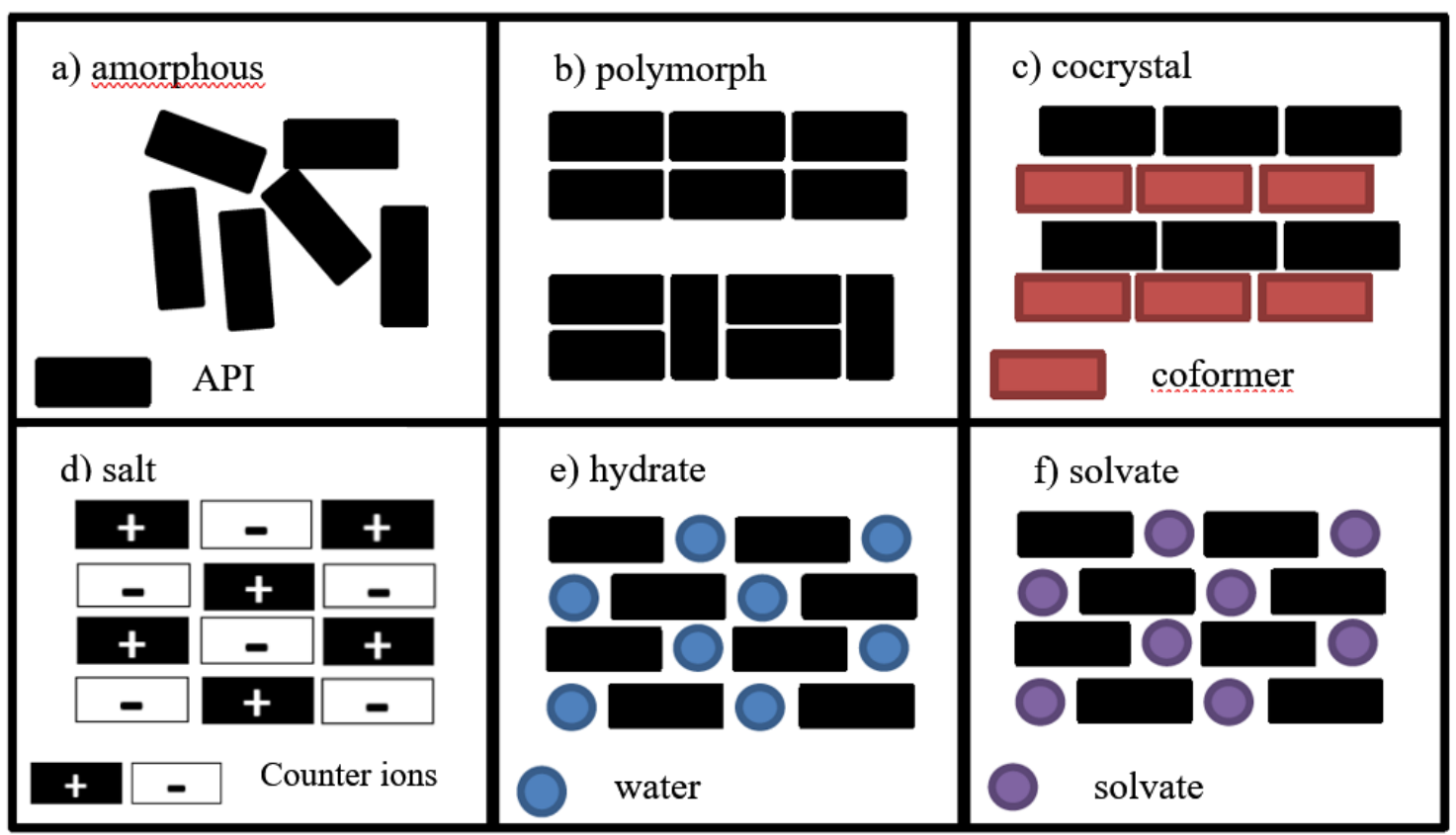

Figure 1. Solid-state forms of API's

Many new drug targets have been identified due to the emergence of new diseases and drug resistance in microbes. The potential molecules discovered are becoming more prominent and more lipophilic. Solubility and dissolution are two main factors in qualifying the activity and efficiency of a drug, and low solubility limits the dissolution rate and absorption of drugs. Appropriate drug dissolution is necessary for proper oral drug therapy. Improving the solubility and dissolution profiles of drugs without altering the molecular structure is a challenge for the successful development of pharmaceutical products (Dizaj et al., 2015; Thakuria et al., 2013). The knowledge of solid-state properties of API in an early stage of drug development helps avoid manufacturing problems (Renkoğlu et al., 2015). Solid forms of API illustrated in Figure 1, which provides different physicochemical properties, are methods that can be used to improve the properties of the API (Blagden et al., 2007).

It is crucial to select the most soluble API form when developing a pharmaceutical drug and requires studying to maintain both stability and resolution of the product. The success of the approaches is dependent on the physicochemical nature of the molecules being studied (Serrano et al., 2016; Shiraki et al., 2008). However, the design of pharmaceutical cocrystals has recently emerged as a potential method to increase the solubility and bioavailability of neutral ingredients (Qiao et al., 2011). There have been various definitions for cocrystals; a general definition utilized by Aakeröy \& Salmon is that cocrystals are structurally homogeneous crystal materials containing two or more components present in specific stoichiometric amounts (Aakeröy \& Salmon, 2005). According to this definition, a pharmaceutical cocrystal is one of its components as an API, and other components are called coformers. Components are linked via non-covalent interactions, hydrogen bonding, $\pi-\pi$ packing, and Van der Waals interactions (Ren et al., 2019).

The most important advantage of cocrystallization is that while enhances the properties of an API without breaking the molecule covalent bonds (Gadade et al., 2017). The effect on the physicochemical properties of the API is dependent on the used coformer. It should be non-toxic and have no adverse effects, which could affect the properties of the API. Other factors like cocrystal size, shape, surface area, dissolution media, and experimental apparatus influenced cocrystal dissolution (Ren et al., 2019; Ross et al., 2016). Some dissolution studies in the literature show that the dissolution of cocrystals is a good predictor of the drug's bioavailability estimation. Serrano et al. have shown in their study how the cocrystal properties change the dissolution. Firstly, they have performed cocrystallization of sulfadimidine and 4-aminosalicylic acid under different conditions. They had obtained large prismatic 
cocrystals (I) when acetone was used as the solvent, and they obtained large plate-like cocrystals (II) when ethanol was used as the solvent. They have grinded the large plate-like to reduce crystal size (III). Also, they have synthesized the cocrystal by liquid-assisted grinding method and obtained the small prismatic cocrystals (IV). They have observed that cocrystal (IV) has the fastest dissolution, followed by cocrystal (III) > cocrystal (I)> cocrystal (II) (Serrano et al., 2016). Nokhodchi et al. have studied phenytoin crystallization by different solvents and its effect on dissolution rate. They have observed rod-shaped particles crystallized by benzene solvent, and dissolution rate was more rapid than rectangular needleshaped crystals crystallized by methanol (Nokhodchi et al., 2003). Shiraki et al. have prepared two cocrystal systems in different particle sizes for dissolution studies. They have resulted in cocrystallization improving to dissolution, and fine cocrystal particles have shown a better dissolution rate (Shiraki et al., 2008). In this study, it is aimed (i) to analyze the dissolution concentration for different forms of cocrystals used in the treatment of psoriasis and (ii) to make a preliminary study to predict how the shape and crystal size difference affects the dissolution and the bioavailability performance of the active ingredient. Ultraviolet-visible (UV-Vis) spectroscopy was used for the dissolution measurement method. Chemical composition of the API in the cocrystals is concealed in the presented work due to restriction. Yet, in further section its significant physical properties are given in detailed.

\section{MATERIALS AND METHOD}

\subsection{Chemicals}

Tween 80 was purchased from Sigma-Aldrich (Berlin, Germany) and was used to prepare 1-liter 0.25 $\mathrm{mg} / \mathrm{ml}$ concentration Tween 80 solution. Hydrochloric acid (\%35) was purchased from PENTA (Chrudium, Czech Republic) and used an acidic solution.

\subsection{Preparation of solutions}

\subsubsection{Tween 80 solution}

1-liter Tween 80 stock solution at a $0.25 \mathrm{mg} / \mathrm{ml}$ concentration was prepared for the acidic solution. $202.5 \mathrm{mg}(190 \mathrm{ml})$ Tween 80 was added to $810 \mathrm{ml}$ distilled water in a 1-liter glass beaker. Mouth of the glass beaker was closed with parafilm and stirred on the magnetic stirrer at room temperature for 24 hours at $300 \mathrm{rpm}$ mixing speed.

\subsubsection{Acidic solution}

Approximately $501 \mathrm{ml}$ acidic solution was prepared for the dissolution concentration studies. $460 \mathrm{ml}$ distilled water and $40 \mathrm{ml}$ Tween 80 solution were added to the $500 \mathrm{ml}$ glass beaker and continuously stirred at $300 \mathrm{rpm}$ and $37^{\circ} \mathrm{C}$ to prepare the acidic solution. While mixing was in progress and controlling via a $\mathrm{pH}$ meter (Mettler Toledo SevenCompact Duo S213 pH/conductivity), around $1 \mathrm{ml}$ hydrochloric acid (11.32M) was added until the $\mathrm{pH}$ level was adjusted to 2.

\subsection{Milling process}

Retsch MM 200 (Retsch, Germany) Vibratory mill was used for the size reduction. 60 mg of cocrystals were grinded at a frequency of $25 \mathrm{~Hz}$. for 10 minutes.

\subsection{Sieving process}

Sieves with $200 \mu \mathrm{m}, 100 \mu \mathrm{m}, 50 \mu \mathrm{m}$, and $25 \mu \mathrm{m}$ sieve openings (Retsch, Germany) were used to limit the crystal size distribution. They were sorted from bottom to top, from the small sieve opening to big sieve openings. Cocrystals were collected in size range of 100-200 $\mu \mathrm{m}, 50-100 \mu \mathrm{m}$, and 25-50 $\mu \mathrm{m}$. 


\subsection{Dissolution Measurement}

Agilent Cary-60 UV-Vis spectrophotometer (Agilent Technologies, Inc., USA) was used with optic fiber probe $10 \mathrm{~mm}$ pathlength. Measurements were carried out wavelength range of 190-500 nanometers $(\mathrm{nm})$ at a scanning speed of $600 \mathrm{~nm} / \mathrm{min}$ with a baseline of acidic solution to prevent the absorption peaks arising from the acidic solution. Absorbance between wavelengths of $300 \mathrm{~nm}$ and $400 \mathrm{~nm}$ was used to evaluate the concentration of API.

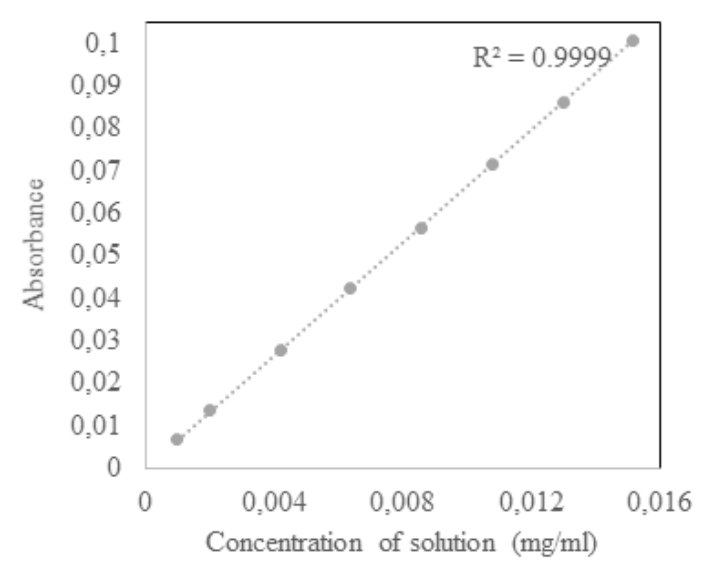

Figure 2. Calibration curve

A calibration curve as shown in Figure 2, was prepared to evaluate the concentration of API at any time point by absorbance value. Eight cocrystals solution was prepared in certain concentrations, 0.0152 $\mathrm{mg} / \mathrm{ml} ; 0.0130 \mathrm{mg} / \mathrm{ml} ; 0.0108 \mathrm{mg} / \mathrm{ml} ; 0.0086 \mathrm{mg} / \mathrm{ml} ; 0.0064 \mathrm{mg} / \mathrm{ml} ; 0.0032 \mathrm{mg} / \mathrm{ml} ; 0.0020 \mathrm{mg} / \mathrm{ml}$ and 0.0010 $\mathrm{mg} / \mathrm{ml}$. They were entirely thawed by stirring all night on the magnetic stirrer at $37^{\circ} \mathrm{C}$ and $300 \mathrm{rpm}$. Absorbance values of the solutions were measured after wholly dissolved. A curve was drawn with the absorbance values versus concentration values of solutions, and the slope of the curve and intersect point the $y$-axis were found. Correlation coefficient $\left(R^{2}\right)$, slope and, the intersection point the $y$-axis were found $0.9999,6.6196 \mathrm{mg} / \mathrm{ml}$ and, $4 \times 10^{-5}$, respectively. The equation to be used to calculate the concentration of API at any time point by using absorbance value was found as

$$
y=6.6196 x+\left(4 \times 10^{-5}\right)
$$

where $\mathrm{y}$ is absorbance value, and $\mathrm{x}$ is concentration.

Dissolution of cocrystals were carried by weighted of $7.5 \mathrm{mg}$ cocrystal powder by Mettler Toledo XSE205 (precision $\sim 0.01 \mathrm{mg}$ ) and placed in $\sim 500 \mathrm{ml}$ acidic solution $\left(\mathrm{pH} 2,37^{\circ} \mathrm{C}\right.$ ) and stirred at $300 \mathrm{rpm}$. Stirring was continued for 2-hours. Aliquots of approximately $3 \mathrm{~mL}$ were withdrawn with a pipette at certain times 5, 10, 20, 30, 45, 60, and $120 \mathrm{~min}$. The samples were analyzed with UV/Vis spectroscopy, and the dissolution concentration of API was calculated with a calibration curve. This process was repeated for each cocrystal sample. A visualized experimental procedure is given in Figure 3. 
1. Preparation of Tween 80 solution at $0.25 \mathrm{mg} / \mathrm{ml}$ concentration

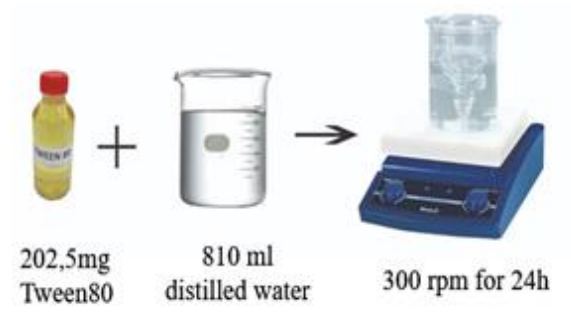

2.Preparation of acidic solution

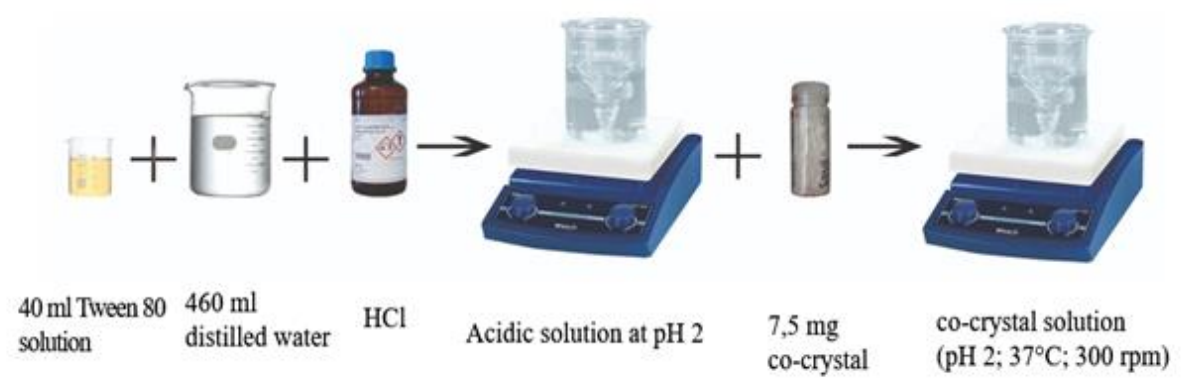

3.Calculation of the dissolution concentration

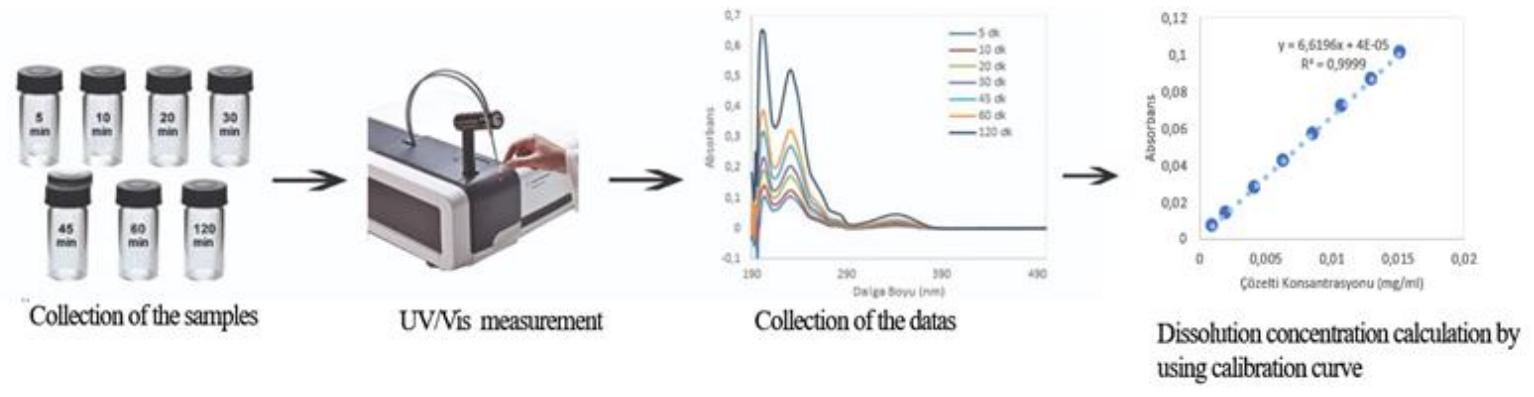

Figure 3. Experimental scheme

\subsection{Cocrystals}

Cocrystals contain API and benzoic acid coformer (molar stoichiometric ratio 2:1). Name and chemical structure of API used in this study are not specified due to restrictions. The cocrystals that resemble the shape of two pyramids joined from their bottoms are called bipyramid. Their surfaces are smoother than the other specimens, with fewer protrusions. The cocrystals having clustering of protrusions from the circumference of the crystal grain are called clump. The shape and size differences of cocrystals depend on the mixer type, mixing time and speed, cooling rate, initial concentration, and some environmental factors (Adhiyaman \& Basu, 2006; Blagden et al., 2007; Bolourtchian et al., 2001). Five different cocrystal samples and a milled form of one cocrystal were used for dissolution concentration evaluation. In some of the cocrystal samples, the distribution of particles was limited by sieving. In Table 1, the abbreviation, and properties of cocrystal samples are given. 
Table 1. Abbreviations and properties of cocrystals

\begin{tabular}{|c|c|}
\hline Cocrystal Code & Cocrystal Properties \\
\hline API-BA-01 & Bipyramid shaped crystals contain particle size between $25-200 \mu \mathrm{m}$ \\
\hline API-BA -01-1 & Cocrystal sample sieved in the range of $50-100 \mu \mathrm{m}$ from API-BA-01 \\
\hline API-BA-01-2 & Cocrystal sample sieved in the range of $25-50 \mu \mathrm{m}$ from API-BA-01 \\
\hline API-BA-02 & Bipyramid shaped crystals contain smaller than $25 \mu \mathrm{m}$ \\
\hline API-BA-03 & Clump shape particles contain size between $50-200 \mu \mathrm{m}$ \\
\hline API-BA-03-1 & Cocrystal sample sieved in the range of $100-200 \mu \mathrm{m}$ from API-BA-03 \\
\hline API-BA-03-2 & Cocrystal sample sieved in the range of $50-100 \mu \mathrm{m}$ from API-BA-03 \\
\hline API-BA-04 & Clump shaped crystals contain smaller than $25 \mu \mathrm{m}$ \\
\hline API-BA-05-1 & Milled cocrystals from API-BA-03 in the range of $20-100 \mu \mathrm{m}$ \\
\hline API-BA-05-2 & Milled cocrystals from API-BA-03 in the range of 50-100 $\mu \mathrm{m}$ \\
\hline API-BA-05-3 & Milled cocrystals from API-BA-03 in the range of $25-50 \mu \mathrm{m}$ \\
\hline API-BA-06 & $\begin{array}{l}\text { Cocrystals synthesized using magnetic stirrer crystal and containing particle } \\
\text { sizes between } 50-200 \mu \mathrm{m}\end{array}$ \\
\hline API-BA-06-1 & Cocrystal sample sieved in the range of $100-200 \mu \mathrm{m}$ from API-BA-06 \\
\hline API-BA-06-2 & Cocrystal sample sieved in the range of $50-100 \mu \mathrm{m}$ from API-BA-06 \\
\hline
\end{tabular}

\section{RESULTS AND DISCUSSION}

\subsection{Determination of the UV spectrum of cocrystal components}

Cocrystals are structurally homogeneous crystalline materials containing two or more components in their structure in a certain stoichiometric ratio (Aakeröy \& Salmon, 2005). For this reason, peaks occur in different wavelength ranges in the UV spectrum. Figure 4 belongs to the UV spectra of API and benzoic acid. While API is absorbed in the range of $290-390 \mathrm{~nm}$ wavelength, benzoic acid is absorbed in the 200$280 \mathrm{~nm}$ wavelength. Since benzoic acid does not absorb in the wavelength range that API is absorbed, the concentration of API can be calculated by the maximum absorbance value of API in the range of 290-390 nm wavelength. 


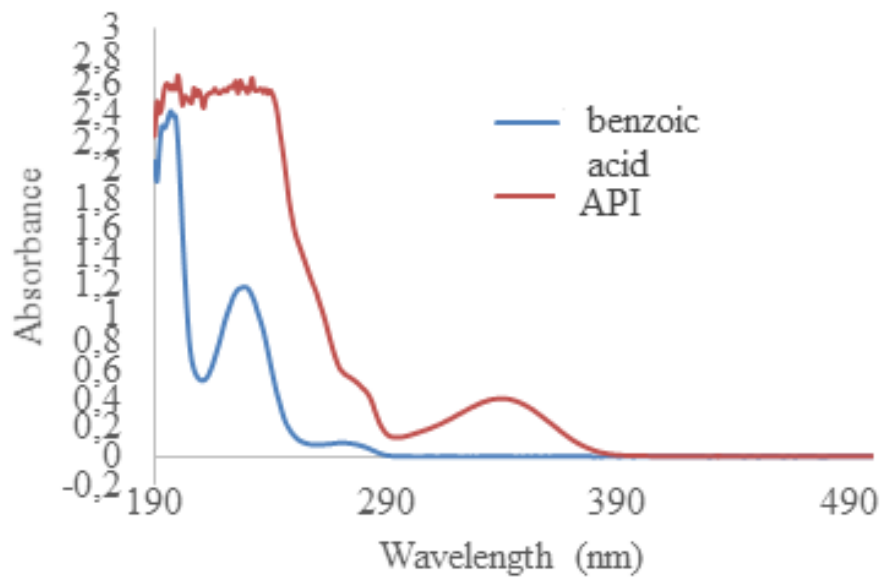

Figure 4. Apremilast and benzoic acid UV/Vis spectrum

\subsection{Evaluation of dissolution concentration}

In order to evaluate the effect of the cocrystal shape on dissolution concentration, different shaped cocrystals limited in the same crystal size range $(50-100 \mu \mathrm{m})$ were compared as given in Figure 5 . It was observed that API-BA-05-2 cocrystal's dissolution concentration was the highest among all the cocrystal samples. Although they have the same crystal size range with API-BA-03-2 cocrystal sample, which is the pre-grinded form, it was observed that they have approximately 3-times higher dissolution concentration value. In this cocrystal sample, it is thought that grinding causes an increase in the total surface area.

To better understand the effect of grinding on the dissolution concentration, different crystal size ranges of API-BA-03 and the grinded API-BA-05 cocrystal samples were compared in Figure 6. In this figure, it can be observed that dissolution concentrations in the different crystal size ranges of API-BA-03 and the grinded API-BA-05 cocrystal samples. It was observed that API-BA-05 cocrystal sample's dissolution concentration was reached the highest value compared to all other crystal size ranges. It was observed that for the cocrystal samples limited to the crystal size range of 50-100 $\mu \mathrm{m}$, the dissolution concentration increased approximately 3 -fold, whereas for the case of grinded the concentration was observed to increase approximately only 2 -fold.

In API-BA-05-3 cocrystal sample, it was observed that the dissolution concentration was reached $0.0187 \mathrm{mg} / \mathrm{ml}$, which is the highest concentration observed in all experiments. In literature, it is mentioned that the grinding process increases the surface area and is used for purposes such as increasing the dissolution and absorption rates (Değim, 2009). In this work, it was observed that the dissolution concentration of the API-BA-01-1 was higher than API-BA-03-2, which were bipyramidal and clump-shaped cocrystals, respectively. The smoother surface of the bipyramidal shape and the fewer protrusions on the surface increased the dissolution concentration. 


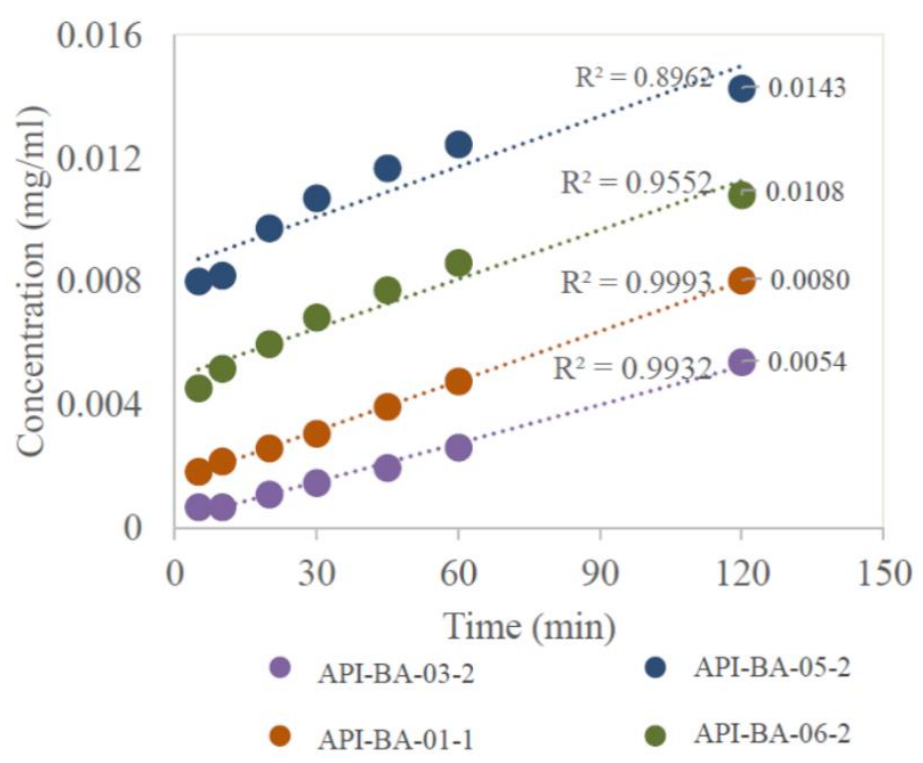

Figure 5. Dissolution concentraion of different shaped cocrystals in 50-100 $\mu \mathrm{m}$ size range

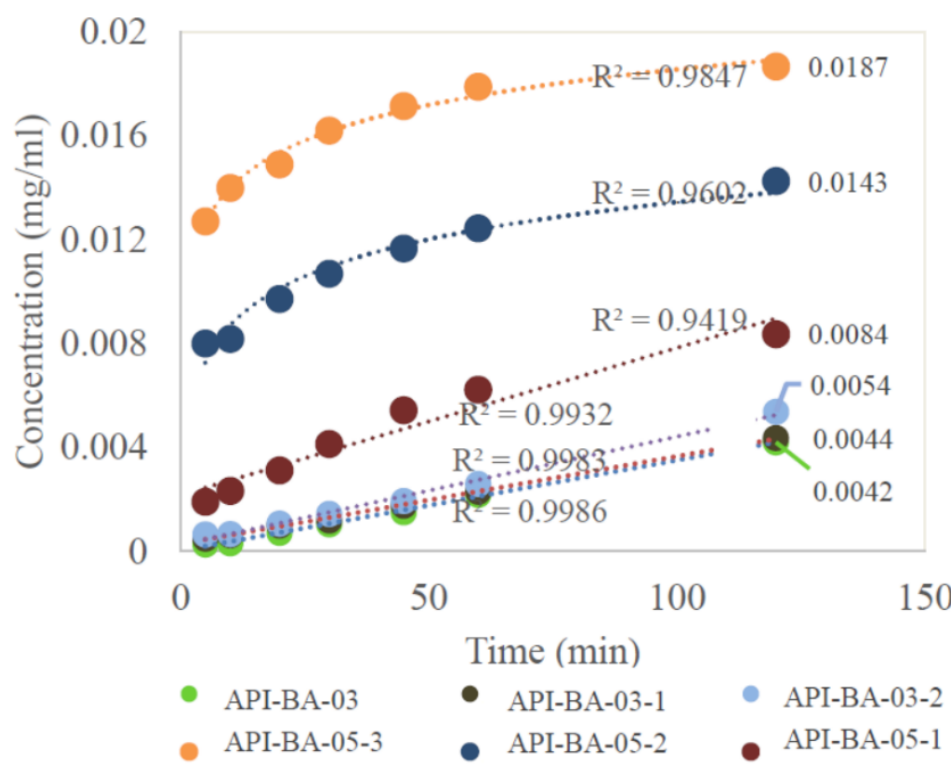

Figure 6. Dissolution comparision of grinded cocrystal

An interesting point can be observed from Figure 5, the dissolution concentration of API-BA-06-2 was reached a higher concentration than API-BA-01-1 and API-BA-03-2. It is known that a magnetic stirrer is used during the synthesis of the API-BA-06 cocrystal sample. It is possible to say that using a magnetic stirrer during synthesis leads to an increase in the total surface area of the cocrystal. (Sun \& Grant, 2001).

API-BA-01 and API-BA-02 samples with bipyramid shapes, were compared to obtain the size effect on the dissolution concentration. It was observed that the dissolution concentration of API-BA-02, containing the crystal particle size smaller than $25 \mu \mathrm{m}$, was reached the higher dissolution concentration, as shown in Figure 7. Likewise, in clump-shaped samples, it was observed that the dissolution concentration of API-BA-04 sample containing cocrystal particles smaller than $25 \mu \mathrm{m}$ was higher, as shown in Figure 8. 


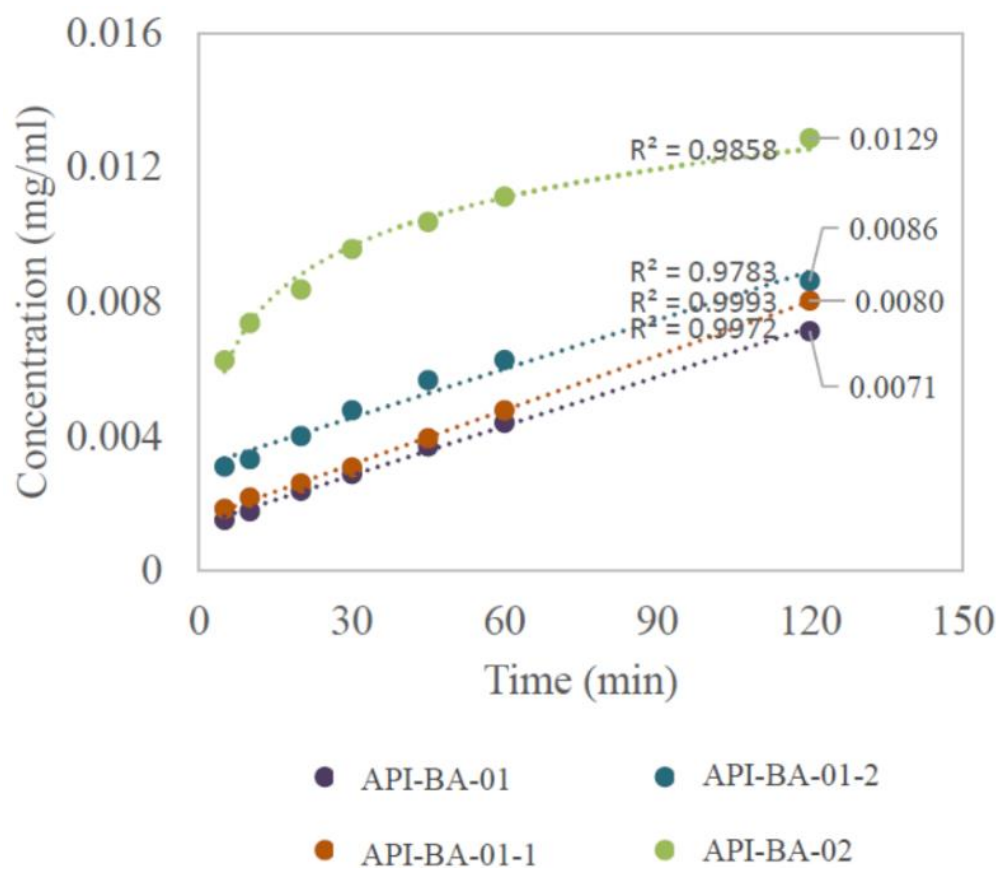

Figure 7. Dissolution concentration of byramidal shaped cocrystals in diffrent size ranges

An increase in dissolution concentration was observed by limiting the crystal size distribution in cocrystal samples of API-BA-01, API-BA-03 as can be seen in Figure 7 and Figure 8. In the API-BA-01 cocrystal sample, the crystal size distribution was limited to $25-50 \mu \mathrm{m}$ and $50-100 \mu \mathrm{m}$. The dissolution concentration, which was $0.0071 \mathrm{mg} / \mathrm{ml}$ before the limitation, was $0.0080 \mathrm{mg} / \mathrm{ml}$ in the range of $50-100 \mu \mathrm{m}$ and $0.0086 \mathrm{mg} / \mathrm{ml}$ in the range of $25-50 \mu \mathrm{m}$. Similarly, in the API-BA-03 cocrystal sample, an increase in dissolution concentration was observed by limiting the cocrystal size distribution.

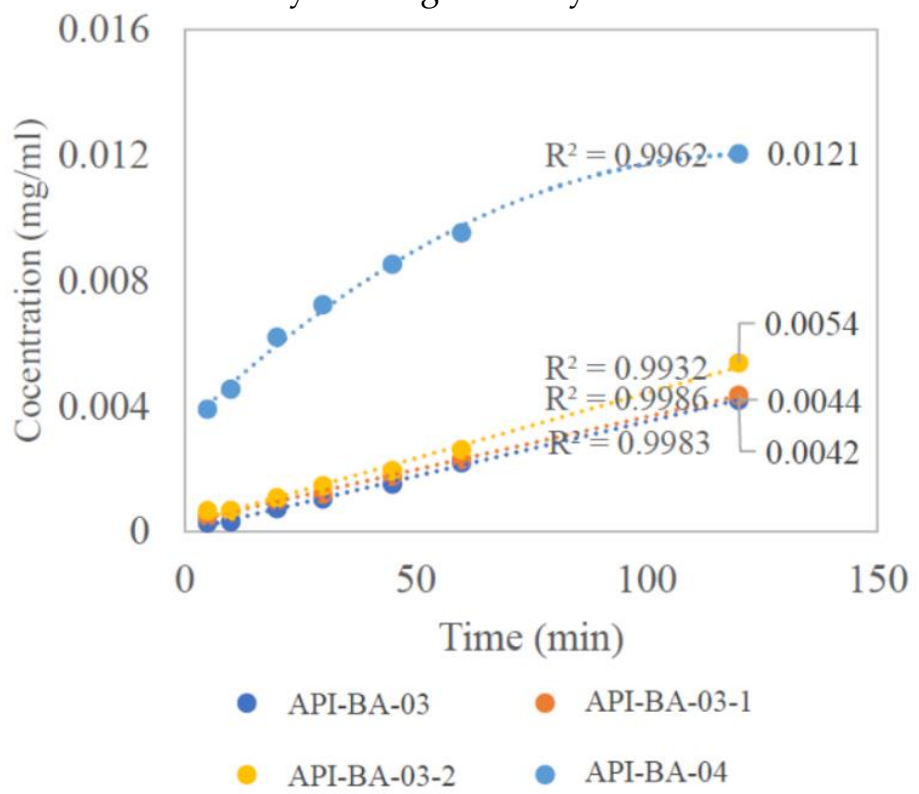

Figure 8. Dissolution concentration of clump shaped cocrystals in diffrent size ranges

It was observed that the dissolution concentration value of crystal samples was less if the crystal size distribution was in a wide range. It is essential to limit the crystal size distribution, increase the dissolution concentration, and provide reproducible properties of the final dosage form (Bukovec et al., 2015). 


\section{CONCLUSION}

In this study, different physical properties effect on dissolution behavior of cocrystals was investigated. Dissolution studies were carried out by preparing an acidic solution similar to $\mathrm{pH}$ level of stomach. Dissolution analysis was performed using cocrystal samples in different shapes and sizes. And also frequently used grinding process effect on crystal samples was considered. It was observed that the dissolution concentration of grinded cocrystal was reached a higher concentration value compared to the pre-grinded form. Also, the grinded sample dissolution concentration of AFB-BA-05-3, having a crystal size range of 25-50 $\mu \mathrm{m}$, had the highest dissolution concentration among all the samples. At the end of 120 minutes, the concentration was reached to $0.0187 \mathrm{mg} / \mathrm{ml}$. These results shows that the grinding process not only reduces the particle size but also increases the surface area. It was observed that the dissolution concentration of API-BA-02 and API-BA-04 cocrystal samples had increased. Also, it was detected that the dissolution concentration increased by limiting the crystal size distribution in the cocrystal samples. It is known from the literature that very small particle size increases contact points hence enhancing the dissolution. The surface properties of the cocrystals have effect on the dissolution. As the surface got smoother and less protruding, the dissolution reached a higher concentration as observed in bipyramid shaped cocrystals. It was proved that the dissolution of cocrystals could be significantly increased with different physical properties. For further investigations it is necessary to measure the total surface area for all cocrystals and bioavailability. It is reported in the literature that dissolution data is a good indicator for the bioavailability performance of the drug. Yet, in vivo studies are necessary to determine the validly of the results obtained in this study for predicting the bioavailability conditions. The cocrystal samples, which have the highest dissolution concentration, offers a higher bioavailability. In the context of this work, AFB-BA-05-3 has the highest dissolution concentration. Thus, further investigations have to be conducted on this cocrystal which has a high chance for dosage reduction amount in psoriasis treatment.

\section{ACKNOWLEDGMENT}

The authors were kindly thankful to the University of Chemistry and Technology, Prague, Laboratory of Bioengineering and Functional Materials members for supporting laboratory studies within the scope of Erasmus+ program.

\section{REFERENCES}

Aakeröy, C. B., \& Salmon, D. J. (2005). Building co-crystals with molecular sense and supramolecular sensibility. CrystEngComm, 7(72), 439-448. https://doi.org/10.1039/b505883j

Adhiyaman, R., \& Basu, S. K. (2006). Crystal modification of dipyridamole using different solvents and crystallization conditions. International Journal of Pharmaceutics, 321(1-2), 27-34. https://doi.org/10.1016/j.ijpharm.2006.04.021

Blagden, N., de Matas, M., Gavan, P. T., \& York, P. (2007). Crystal engineering of active pharmaceutical ingredients to improve solubility and dissolution rates. In Advanced Drug Delivery Reviews. https://doi.org/10.1016/j.addr.2007.05.011

Bolourtchian, N., Nokhodchl, A., \& Dinarvand, R. (2001). The effect of solvent and crystallization conditions on habit modification of carbamazepine. DARU Journal of Pharmaceutical Sciences $9(1), 12-22$.

Bukovec, P., Meden, A., Smrkolj, M., \& Vrečer, F. (2015). Influence of crystal habit on the dissolution of simvastatin single crystals. Acta Chimica Slovenica, 62(4), 958-966. https://doi.org/10.17344/acsi.2015.1849

Chan, E. J., Gao, Q., \& Dabros, M. (2014). Understanding the structure details when drying hydrate crystals of pharmaceuticals - Interpretations from diffuse scattering and inter-modulation satellites of a partially dehydrated crystal. Acta Crystallographica Section B: Structural Science, Crystal Engineering and Materials, 70(3), 555-567. https://doi.org/10.1107/S2052520614005125 
Değim, Z. (2009). Öğütme. In Modern Farmasötik Teknoloji (1st ed., pp. 3-8). TEB Eczacılık Akademisi. http://e-kutuphane.teb.org.tr/pdf/tebakademi/modern_farmasotk/3.pdf

Dizaj, S. M., Vazifehasl, Z., Salatin, S., Adibkia, K., \& Javadzadeh, Y. (2015). Recrystallization of drugs: Effect on dissolution rate. In V. Glebovsky (Ed.), Research in Pharmaceutical Sciences (pp. 191211). https://www.intechopen.com/books/recrystallization-in-materials processing/recrystallization-of-drugs-effect-on-dissolution-rate

Gadade, D. D., Pekamwar, S. S., Lahoti, S. R., Patni, S. D., \& Sarode, M. C. (2017). Etodolak'ın kokristalizasyonu: Ko-kristalizasyon tahmini, ko-kristal sentezi, katı faz yapı aydınlatma Çalışmaları ve in vitro İlaç salımı. Marmara Pharmaceutical Journal, 21(1), 78-88. https://doi.org/10.12991/marupj.259884

Nokhodchi, A., Bolourtchian, N., \& Dinarvand, R. (2003). Crystal modification of phenytoin using different solvents and crystallization conditions. International Journal of Pharmaceutics, 250(1), 85-97. https://doi.org/10.1016/S0378-5173(02)00488-X

Qiao, N., Li, M., Schlindwein, W., Malek, N., Davies, A., \& Trappitt, G. (2011). Pharmaceutical cocrystals: An overview. International Journal of Pharmaceutics, 419(1-2), 1-11. https://doi.org/10.1016/j.ijpharm.2011.07.037

Ren, S., Liu, M., Hong, C., Li, G., Sun, J., Wang, J., Zhang, L., \& Xie, Y. (2019). The effects of pH, surfactant, ion concentration, coformer, and molecular arrangement on the solubility behavior of myricetin cocrystals. Acta Pharmaceutica Sinica B, 9(1), 59-73. https://doi.org/10.1016/j.apsb.2018.09.008

Renkoğlu, P., Çelebier, M., \& Arica, B. (2015). HPLC determination of olanzapine and carbamazepine in their nicotinamide cocrystals and investigation of the dissolution profiles of cocrystal tablet formulations. Pharmaceutical Development and Technology, 20(3), 380-384. https://doi.org/10.3109/10837450.2014.882937

Ross, S. A., Lamprou, D. A., \& Douroumis, D. (2016). Engineering and manufacturing of pharmaceutical co-crystals: A review of solvent-free manufacturing technologies. Chemical Communications, 52(57), 8772-8786. https://doi.org/10.1039/c6cc01289b

Schultheiss, N., \& Newman, A. (2009). Pharmaceutical cocrystals and their physicochemical properties. Crystal Growth and Design, 9(6), 2950-2967. https://doi.org/10.1021/cg900129f

Serrano, D. R., O'Connell, P., Paluch, K. J., Walsh, D., \& Healy, A. M. (2016). Cocrystal habit engineering to improve drug dissolution and alter derived powder properties. Journal of Pharmacy and Pharmacology, 68(5), 665-677. https://doi.org/10.1111/jphp.12476

Shiraki, K., Takata, N., Takano, R., Hayashi, Y., \& Terada, K. (2008). Dissolution improvement and the mechanism of the improvement from cocrystallization of poorly water-soluble compounds. Pharmaceutical Research, 25(11), 2581-2592. https://doi.org/10.1007/s11095-008-9676-2

Sun, C., \& Grant, D. J. W. (2001). Influence of crystal structure on the tableting properties of sulfamerazine polySun, C., \& Grant, D. J. W. (2001). Influence of crystal structure on the tableting properties of sulfamerazine polymorphs. Pharmaceutical Research, 18(3), 274-280. doi:10.1023. Pharmaceutical Research, 18(3), 274-280. https://doi.org/10.1023/A:1011038526805

Thakuria, R., Delori, A., Jones, W., Lipert, M. P., Roy, L., \& Rodríguez-Hornedo, N. (2013). Pharmaceutical cocrystals and poorly soluble drugs. International Journal of Pharmaceutics, 453(1), 101-125. https://doi.org/10.1016/j.ijpharm.2012.10.043 